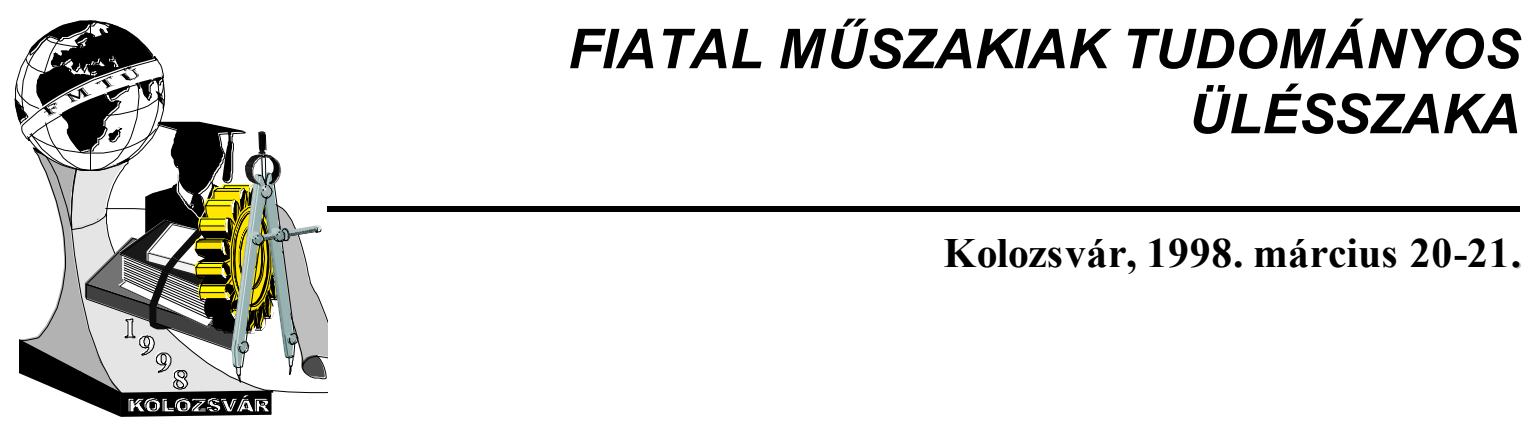

\title{
Módszer az időben változó dendritcsúcs sugár gyors meghatározására
}

\author{
Réger Mihály
}

\begin{abstract}
One of the most important structural parameters of the dendritic structure is the radius of the primary dendritic tip, i.e. the radius of curvature of the dendritic tip. There are two common methods for the description and the approximation of the dendritic tip: the hemispherical tip and the paraboloid. The shape of the paraboloid near the tip can be described by the biggest sphere that can be matched to the tip of the paraboloid from inside. This paper introduces a method which is based on image analysis and which can be used for the exact definition of the radius of curvature (the radius of the sphere matching from inside) characteristic of the tips of the primary dendritic branches. The aim of development of this method is a fast and accurate determination of the radius of curvature of dendrites formed in a succionitrile-acetone system under non steady state condition.
\end{abstract}

\section{Bevezetés}

A dermedés utáni mikroszerkezet többek között a kristályosodási viszonyok függvényében alakul ki. E viszonyok - reális, üzemi körülmények között - időben folyamatosan változnak, így az általuk létrehozott szerkezet is pontról pontra változik (nem állandósult állapot). A kialakult szerkezet jellemzésére az un. primer szerkezeti jellemzők szolgálnak, ezek közül a legfontosabbak a primer, szekunder és tercier dendritág távolság valamint a dendritcsúcs sugara. Ezen jellemzők kézbentartásának, szabályozásának szükségességét az indokolja, hogy igen szoros kapcsolatban állnak mind a technológiai paraméterekkel, mind a gyakorlati, felhasználói tulajdonságokkal. E szerkezeti jellemzőkkel kapcsolatosan igényként merült fel statisztikus jellegük miatt -, hogy az elméleti és gyakorlati következtetések nagyszámú mérésen alapuljanak. A dolgozat a fent említett egyik szerkezeti jellemzőre, a dendritcsúcs sugárra nézve mutat be olyan, képelemzésen alapuló meghatározási módszert, amely ezen 
igényeket kielégíti, s mellyel lehetőség nyílik e szerkezeti jellemző változását a nem állandósult állapotú kristályosodás viszonyai között nyomon követni.

\section{Kísérleti munka}

Az állandósult állapotú irányított kristályosodás vizsgálatának egyik jól bevált kísérleti anyaga a borostyánkősav-dinitril (succinonitrile) - aceton elegy, mely $56{ }^{\circ} \mathrm{C}$ környékén a fémes anyagokkal teljesen analóg módon kristályosodik [1-3]. Mind az olvadék, mind a kristályos fázis vékony rétegben átlátszó, így az anyag kristályosodása pl. két üveglap között közvetlenül megfigyelhetö.

A nem állandósult állapotot a mintatartó mozgási sebességének - ezáltal a mintatartóban kialakuló hűlési sebességnek - egy állandó értékről egy másik állandó értékre történő hirtelen megváltoztatásával lehet előidézni. Ennek eredményeképpen a kristályosodás folyamatában tranziens (két állandósult állapot közötti) jelenség zajlott le, melynek során a dendritcsúcs sugár folyamatosan változik. A kísérleti kristályosító berendezés és az azzal végzett kísérleti munka részletes ismertetése más publikációkban megtalálhatók [4-6].

\section{Mérési eljárás}

A dendritcsúcs sugár a dendrit csúcsán mérhető görbületi sugár, melynek becsléséhez a dendritalak formájára vonatkozó, valamilyen modell feltételezése szükséges. A dendritalak modellezésére (a diffúziós folyamatok leírása céljából) több eljárás is kialakult (pálcika, lemez, forgási paraboloid), ezek közül a dendritcsúcs környéki viszonyok a forgási paraboloid alakkal követhetők a legjobban [7]. Egy forgási paraboloidnak a tengelyén átmenő síkmetszete parabola alak, vagyis az átlátszó modellanyag dendritek csúcsa közelében a külső kontúr parabolával közelíthető.

A kidolgozott eljárás elvi alapja az, hogy a

$y=a x^{2}+b x+c$

alakú parabola csúcsában a $\rho$ görbületi sugár a parabola

$p=\frac{1}{2|a|}$

paraméterével egyezik meg, azaz $\rho=p[8]$. 
Ennek megfelelően ha sikerül a csúcs közelében megfelelő mennyiségü kontúrpontra másodfokú parabolát illeszteni, akkor a regressziószámítás eredményéből a paraméter, illetve a csúcsponti sugár egyszerüen számítható. Az eljárás alkalmazhatóságának feltétele, hogy a dendrit tengelye és az illesztett parabola szimmetriatengelye egybe essen.

A videoszalagon rögzített felvételek kiértékeléséhez, - a nagy adatmennyiség miatt mindenképpen számítógépes képelemző eljárást kellett kidolgozni. Első lépésként, az állandósult állapotot mutató felvétel részletek elemzésével foglalkoztunk, melynek eredményei publikációk formájában napvilágot láttak $[9,10]$.

Nem állandósult állapotban a csúcs sugara pillanatról pillanatra, néha igen gyorsan változik, így megfelelő idő felbontás eléréséhez nagy számú kép kiértékelése vált szükségessé. A VIRGINIA képelemző szoftver a feladathoz megfelelőnek bizonyult. Képbeolvasó kártyával digitalizált képeken a szoftver különböző funkcióinak alkalmazásával előállítottuk a dendritcsúcs környékének kontúrját. A kontúrpont koordináta sorra - megfelelő átalakítások után -, kereskedelmi szoftverek segítségével (ORIGIN, EXCEL) másodfokú parabolát illesztve kiszámítható a parabola görbületi sugara. A dendrites képekkel együtt feldolgozott, hitelesítő jelzéseket tartalmazó képek adatai alapján a parabola paramétere hiteles görbületi sugárra számolható át.

A bemutatott eljárás tranziens folyamatok követésére való használhatóságát jól mutatja az a tény, hogy az előkísérleteket nem számítva, néhány nap alatt több, mint 200 felvétel kiértékelését végeztük el [11].

\section{Következtetések}

A dolgozatban bemutatott eljárással a dendrit csúcsában mérhető görbületi sugár gyorsan és megbízhatóan határozható meg. A képelemzésen alapuló, reprodukálható mérési módszer alkalmazásával lehetőség nyílik a nagyobb sebességü, nem állandósult állapotú folyamatok követésére is, illetve kellő számú mérés elvégzésével, a dendritcsúcs sugár változásának előrejelzésére szolgáló kinetikai modell megalkotására is.

A dolgozatban bemutatott, kristályosodás terén végzett kutatási tevékenységet az OTKA (F4358), valamint a Múvelődésügyi Minisztérium (MKM 448) támogatta. A támogatást ezúton is köszönjük. 


\section{Hivatkozások}

[1] M.E. Glicksman: Met. Trans. A, Vol. 7A, November, pp. 1747-1759, 1976.

[2] S.C. Huang, M.E. Glicksmann: Acta Metall., Vol. 29, pp. 701-715, 1981.

[3] K. Somboonsuk et al.: Met. Trans. A, Vol. 15A, pp. 967-975, 1984.

[4] Réger M.: Temperature distribution of transient crystallizer, Mat. Sci. Forum, Vols. 215-216, Trans. Tec. Publications, pp.511-516, 1996

[5] Réger M.: Kristályosodási tranziens folyamatok vizsgálata, Bányászati és Kohászati Lapok, Kohászat, Vol. 128, 5, pp. 1995.

[6] Réger M.: A számítógép szerepe az irányított kristályosodási folyamatok vizsgálatában, microCAD'96, Miskolci Egyetem, Miskolc, 1996.

[7] W. Kurz, D.J. Fischer: Fundamentals of Solidification, Third Ed., Trans Tech Publications, 1992.

[8] I.N. Bronstejn, K.A. Szemengyajev: Matematikai Zsebkönyv, MK, Budapest, 1987.

[9] Réger, M., Gácsi, Z., Csepei, Zs.: Method for Quick Measuring of Dendrite Tip Using Image Analyser, Proc. of Int. Conf. on the Quantitative Description of Materials Microstructure, Warsaw, pp. 445-450, 1997.

[10] Réger, M., Gácsi, Z., Csepei, Zs.: Determination of Dendrite Tip Shape Using Image Analyser, Proc. of the Second International Congress in Materials Science and Engineering, Jassy, Romania, pp. 567-573, 1997.

[11] A. Björk (Borlänge University): Determination of dendrite tip radius by using image analysis, Examwork, BDMF, 1997.

dr. Réger Mihály, föiskolai docens

Bánki Donát Múszaki Főiskola, Anyag- és Alakítástechnológiai Tanszék

H-1081 Budapest, Népszínház u. 8.

Email: reger@zeus.banki.hu, Tel.: 36-1-3134-094, Fax.: 36-1-3336-761 